\title{
L'Homme d'outre-mer
}

A NEw series of publications with this general title is appearing under the auspices of the Office de la Recherche Scientifique et Technique Outre-Mer, Paris. The series is to comprise reports of studies and field researches carried out under the direction of ORSTOM and the Conseil Supérieur des Recherches Sociologues Outre-Mer. The first of the series is a demographic survey of the peoples of Moyen Logone (Tchad et Cameroun) carried out by two geographers, Jean Cabot and Roland Diziain. It gives a brief account, with maps and diagrams, of the geography of the area, the ethnic distribution, and the traditional economy of the people-land-use, cattle-keeping, markets, \&c.; there are short descriptions of marriage custom and inheritance, but the main interest is in economic development. There are numerous tables showing areas cultivated and crops grown in each village and by each family, with calendars of seasonal agricultural operations, as well as population tables showing age and sex percentages; the book includes a number of photographs and a map showing ethnic distribution.

M. Hubert Deschamps, Secretary of the Conseil Supérieur and Director of Social Studies for ORSTOM, in his preface to the volume, refers to the growing recognition in France of the value of the social sciences and the support now given by official bodies to the work of social scientists. He points out that the territory with which the present volume is concerned presents peculiar ecological features and has been the site of ambitious projects for the reclamation of land and its protection from inundation by the River Logone with a view to the development of permanent cultivations.

\section{'The New Nation'}

A NEw venture in missionary journalism has been launched in the Gold Coast with the publication of The Nen Nation, a popular illustrated monthly, the first number of which appeared in July 1955 . It is an interdenominational enterprise, supported by the Evangelical Alliance and warmly welcomed by the Christian Council of the Gold Coast. The aim of the paper is ' to encourage Christian thinking on contemporary problems '; it contains articles written by specialists in many fields (medicine, agriculture, economics), but it is designed to appeal primarily to ordinary families. The first number includes an article by a Gold Coaster in London, articles on cocoa, on meteorology, instalments of two serial stories, a woman's page, news items from the Gold Coast, India, and London, and two historical articles.

\section{Fifth Congress of Anthropological and Ethnological Sciences}

Aт the invitation of the American Anthropological Association and the University Museum, University of Pennsylvania, the Vth Congress of Anthropological and Ethnological Sciences will be held at Philadelphia, from I to 9 September 1956 . One paper will in principle be accepted from each participant, without prejudice to additional contributions requested for presentation at General Sessions. Abstracts should be in hand by I March 1956.

Inquiries should be addressed to the Secretary, American Organizing Committee, International Congress of Anthropology, National Academy of Sciences-National Research Council, 2 IOI Constitution Avenue, Washington 25, D.C., U.S.A. Cable Address NARECO.

I Population du Moyen Logone (Tchad et Cameroun), par J. Cabot et R. Diziain, 1955. Paris: Office de la Recherche Scientifique et Technique Outre-Mer. Pp. 76, cartes, illus. 